\title{
Recent Developments in California's Last Clear Chance Doctrine
}

\author{
Myron L. Garon*
}

R ECENT CASES indicate that California's Last Clear Chance doctrine is 1 undergoing a modification that makes it available in an increasingly large number of negligence cases. These recent developments make desirable a brief re-examination of the entire doctrine, in order that the new developments can be viewed in proper perspective. The doctrine should also be compared with its principal alternative, Comparative Negligence.

\section{What is Last Clear Chance?}

The doctrine of Last Clear Chance may be defined as a reasoning process used in analyzing the facts of an accident situation in which the following elements are present:

1. The plaintiff has been negligent, and as a result, he is in a position of danger of which he is wholly unaware, or from which he cannot escape by the exercise of ordinary care.

2. The defendant has knowledge that the plaintiff is in a position of danger, and knows, or in the exercise of ordinary care should know, that plaintiff cannot escape from his position of danger. ${ }^{1}$

3. The defendant has the last clear chance to avoid the occurrence by the exercise of ordinary care, and fails to exercise that care; the plaintiff being injured as a proximate result of the defendant's subsequent and final negligence. ${ }^{2}$

Ordinarly, if the plaintiff has been negligent, the rule of contributory negligence prevents him from recovering damages from the defendant, though the latter has also been guilty of ordinary negligence. However, under the Last Clear Chance doctrine, though the plaintiff's own negligence placed him in a position of danger, he is given a second chance, and the rule of contributory negligence does not bar recovery of damages. But the doctrine does not wholly eliminate the rule of contributory negligence, for if after having gotten himself into a position of danger, the plaintiff, realizing his peril, fails to use ordinary care to extricate himself, he is guilty of "continuing negligence" which does prevent him from recovering damages from the defendant. ${ }^{3}$

As was said in Jacobsen v. Vaughn," "There is a distinction between the negligence of a party through which he is placed in a position of peril and a further or continued negligence through which he fails to take measures

* Member of Los Angeles Bar.

1 Gillette v. City of San Francisco, 58 Cal. App. 2d 434, 442, 136 P.2d 611, 615 (1943).

2 Girdner v. Union Oil Co., 216 Cal. 197, 13 P.2d 915 (1932); Poncino v. Reed Murdock \& Co., 136 Cal. App. 223, 28 P.2d 932 (1934); see Catrforna JURY Instructions, CivIn, No. 205 (Supp. 1950, 1952).

3 Jacobsen v. Vaughn, 131 Cal. App. 277, 283, 21 P.2d 141, 143 (1933).

4 Ibid. 
to escape which are available to him. The entire doctrine has reference to a situation in which a party may have been negligent in getting into a perilous situation. If that negligence continues, in the sense that the party does not avail himself of an opportunity open to him to escape from the perilous situation, the doctrine cannot benefit him. On the other hand, though his peril be created by his own negligence, if he has no opportunity to escape, while the other party, knowing his situation, does have the opportunity to avoid the injury, the doctrine applies."

\section{Early History of the Doctrine in California}

The genesis of the Last Clear Chance doctrime in California is found in the case of Needham v. San Francisco and San Jose Railroad, ${ }^{5}$ which held that even if the plaintiff were guilty of negligence or even of positive wrong in placing his animals on a railroad track, the railroad company was still bound to exercise reasonable care and diligence in the use of its road; and if for want of that care, the animals were injured, the company was liable.

The first attempt at classification of the elements of the doctrine in California was undertaken by the supreme court in the case of Palmer $v$. Tschudy: ${ }^{6}$.

(1) The last clear chance rule presupposes: that the plaintiff has been negligent; that as a result thereof she is in a situation of danger from which she cannot escape by the exercise of ordinary care; that the defendant is aware of her dangerous situation under such circumstances that he realizes, or ought to realize, her inability to escape therefrom; that lie then has a clear chance to avoid injuring her by the exercise of ordinary care, and fails to do so. If all of these elements are present the rule applies and enables the plaintiff to recover, notwithstanding her own negligence. But if any of them be absent the rule does not apply and the case is governed by the ordinary rules of neghigence and contributory negligence. (2) The rule does not require that the inability of the plaintiff to escape the danger shall be due to a situation which renders it physically impossible for ler to do so. It applies equally when she is wholly unaware of the danger and for that reason unable to escape it. But the rule also requires that if she is aware of the danger, or becomes aware of it, she must thereafter exercise ordinary care for her own protection.

Three items which the court failed to include in this classification are: ${ }^{7}$

1. That defendant knows facts from which he ought to realize that plaintiff is in a position of danger;

2. That defendant knows that plaintiff is iguorant of danger;

3. That defendant is under a duty to use ordinary care to avoid the occurrence.

All three items had been recoguized in earlier cases ${ }^{7 \mathbf{a}}$ and have been mentioned also in inore recent cases. The first item, the defendant's knowl-

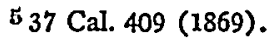

6191 Cal. 696, 700, 218 Pac. 36, 37 (1923).

7 HaIr, LAST CLEAR CaANCE 23 (1939).

7a Infra notes 8 and 9. 
edge of facts from which he ought to realize that plaintiff is in a position of danger, was recognized in the very recent case of Selinsky v. Olsen. ${ }^{8}$ The second item, the defendant's knowledge that planitiff is ignorant of the danger, was emphasized in the recent case of Peterson v. Burkhalter. ${ }^{\circ}$

\section{Later History of the Doctrine}

Last Clear Chance and "continuing negligence" are mutually exclusive doctrines. If the factual situation gives rise to one doctrine, the other does not apply. The landmark case that first recognized this fundamental fact is Girdner v. Union Oil Co. ${ }^{10}$ Briefly, the essential facts are that the plaintiff, approaching a highway from the east, looked north when still some distance from the highway, but seeing no cars, looked south and did not look north again. Thus he drove slowly into the highway, looking only south as he entered. He never saw the defendant, who struck him from the north.

The defendant, driving slowly from the north, saw the plaintiff, who was 50 feet from the intersection, driving very slowly, and not looking towards defendant at any time. Defendant took his foot off the gas and drifted into the intersection without sounding his horn, and without applyily his brakes until he was about 15 feet from the plaintiff. The trial court found that defendant had sufficient time and distance within which to stop.

The supreme court held that the facts justified a recovery for the plaintiff under the Last Clear Chance doctrine. It declared the continuing negligence rule to be "... a determination that the facts involved do not bring into operation the latter doctrine [Last Clear Chance], but involve inerely the ordinary and contributory negligence which will bar recovery in any case." 11

838 A.C. 102, 237 P.2d 645 (1951). Also recognized in many older cases, e.g., Wallis v. Southern Pacific Co., 184 Cal. 662, 673, 195 Pac. 408, 412 (1921) ; Basham v. Southern Pacific Co., 176 Cal. 320, 324, 168 Pac. 359, 360 (1917) ; Arnold v. San Francisco O.T. Ry., 175 Cal. 1, 4, 164 Pac. 798, 800 (1917) ; Paulos v. Market St. Ry., 136 Cal. App. 163, 169, 28 P.2d 94, 96 (1934) ; Gainer v. United Railroads of S.F., 58 Cal. App. 459, 208 Pac. 1013 (1922).

938 A.C. 109, 237 P.2d 977 (1951). Also recognized in many older cases, e.g., Wallis v. Southern Pacific Co., supra note 8 at 673, 195 Pac. at 412 (1921); Basham v. Southern Pacific Co., supra note 8; Townsend v. Butterfield, 168 Cal. 564, 569, 143 Pac. 760, 762 (1914); Harrington v. Los Angeles Ry., $140 \mathrm{Cal}$. 514, 526, 74 Pac. 15, 19 (1903); Keene v. United Railroads of San Francisco, 57 Cal. App. 124, 207 Pac. 35 (1922). The third point, duty to use care, is recognized in Young v. Southern Pacific Co., 189 Cal. 746, 210 Pac. 259 (1922) ; Basham v. Southern Pacific Co., supra note 8; Keyes v. Geary St. R. R., 152 Cal. 437, 93 Pac. 88 (1907) ; Henderson v. Los Angeles Traction Co., 150 Cal. 689, 89 Pac. 976 (1907); Harrington v. Los Angeles Ry., 140 Cal. 514, 74 Pac. 15 (1903); Lee v. Market St. Ry., 135 Cal. 293, 67 Pac. 765 (1901) ; Fox v. Oakland Consolidated St. Ry., $118 \mathrm{Cal}$. 55, 50 Pac. 25 (1897); Holmes v. Southern Pac. Coast Ry., 97 Cal. 161, 31 Pac. 834 (1893) ; London Guarantee \& Accident Co. v. Southern Pac. Co., 53 Cal. App. 599, 200 Pac. 805 (1921); Tlardi v. Central California T. Co., 36 Cal. App. 488, 172 Pac. 763 (1918); Furtado v. Bird, 26 Cal. App. 152, 146 Pac. 58 (1914) ; Kramm v. Stockton Elec. R. R., 22 Cal. App. 737, 136 Pac. 523 (1913); Ruppel v. United Railroads, 10 Cal. App. 319, 101 Pac. 803 (1909); Matteson v. Southern Pacific Co., 6 Cal. App. 318, 92 Pac. 101 (1907); Johnson v. Center, 4 Cal. App. 616, 88 Pac. 727 (1906).

10216 Cal. 197, 13 P.2d 915 (1932).

11 Id. at 201, 13 P.2d at 917. 


\section{Recent Development of the Doctrine}

The Selinsky $y^{12}$ and Peterson ${ }^{13}$ cases mark a turning point in the development of the Last Clear Chance doctrine. Both were decided in November, 1951. The fact that the supreme court entertained petitions for hearing m these two cases so close together after decisions by the district courts mdicated that something was brewing. The results are expressed in Justice Schauer's opinion, dissenting from the Peterson decision, in which he says, "The standard of conduct required of the defendant in this case exceeds that imposed in any reported case which has come to my attention . . . . The tendency of courts in recent years to extend application of the Last Clear Chance doctrine has been manifest. I think there should be a limit to its extension and this case passes reasonable bounds." 14 Let us examine these two cases to determine just what the court had done that Justice Schauer found so objectionable.

The plaintiff in the Selinsky case started to take his car out of parking. Before doing so, he looked through rear view mirrors on both the inside and the outside of the car, and observed no moving cars on the street near him. There was a car parked 5 or 6 feet in front of him, and another parked 25 feet behind him. Plaintiff pulled away from the curb, and when the left front end of the car was protruding 2 feet into the traffic lane, his motor stalled. Five seconds later, according to the plaintiff, and one minute later according to another witness, while the car was still in that position, defendant collided with the left front of it.

The defendant testified that he had not seen planitiff's car until he was only 15 feet behind the front of it, but he admitted that his view had been unobstructed. His admissions and other testimony indicated that he had been looking straight ahead and could have seen a protruding car for a distance of 50 feet, and that he had been traveling at only about 20 to 25 miles per hour. Defendant further testified first that he tried to swerve to the left, but later that he did not remember so doing, and that he applied his brakes when he saw plaintiff's car.

The trial court granted a motion for new trial after a judgment for defendant, on the grounds of error in refusing to instruct on Last Clear Chance. The appellate court reversed the order, holding, as a matter of law:15

1. That defendant did not know plaintiff was in a perilous position;

2. That defendant did not realize plaintiff was unable to escape from his dangerous situation, or whether plaintiff was unaware of his danger;

3. That defendant did not have a clear chance to avoid the accident;

4. That since, as a matter of law, all the elements of the doctrine did not appear from the evidence, the trial court erred $\mathrm{m}$ granting a motion for a new trial.

12 Supra note 8.

13 Supra note 9.

14 Id. at 115,237 P.2d at 981.

15229 P.2d 392 (1951). 
The California Supreme Court reached a different conclusion, and affirmed the order of the trial court, holding that where evidence is conflicting, it is for the jury to determine whether the plaintiff was in a position of danger from which he could not extricate himself by the use of ordinary care, the court saying: ${ }^{18}$

It may be true that plaintiff was negligent in pulling away from the curb and was aware of his dangerous position, but when his car was protruding mto the lane of traffic, his motor stalled, and the jury could infer that he was incapable of extricating himself by the exercise of ordinary care. Plaintiff's car was stopped from five seconds to a minute before the collision.

The court also held that it is for the jury to determine whether the defendant had actual knowledge of plaintiff's perilous situation and knew or should have known that plaintiff was unable to escape from danger. The court declared: ${ }^{17}$

... [D]efendant was looking straight ahead as he approached plaintiff's car and his view was unobstructed. It may be inferred therefrom that he saw plaintiff's motionless car extending into the line of traffic .... The jury could have inferred also, that defendant knew or should have known, in the exercise of ordinary care, that plaintiff could not escape.

The court further held that the jury must decide whether the defendant was the last to have a clear chance to avoid the accident, saying: ${ }^{18}$

... [I]t was for the jury to determine whether in the space of time involved he could have avoided the collision .... We cannot say as a matter of law that he did not, by exercising ordinary care, have the last clear chance to avert the collision-something more than a split second possible clrance.

The Peterson case, decided at almost the same time, shows a slightly different approach. In that case, the plaintiff, a minor, was traveling towards an intersection at approxinately 30 miles per hour and was looking over his shoulder in the opposite direction from that in which he was traveling. Defendant, who was driving in the cross street, going 15 to 20 miles per hour, observed these facts while still 50 feet from the intersection, at which time plaintiff was about 75 feet from the intersection. Defendant looked away, and when next he saw plaintiff, the scooter was only 4 to 5 feet from the car, and plaintiff was still looking over his shoulder. Defendant did not sound his horn, apply his brakes, or change direction before the accident. Defendant testified he tried to accelerate to avoid plaintiff, but he was unable to avert the collision.

Defendant contended on appeal that none of the required elements of the Last Clear Chance doctrine were present, and that judgment must be entered in his favor because the evidence showed, as a matter of law, that plaintiff was guilty of contributory negligence.

16 Selinsky v. Olsen, supra note 8 at 105, 237 P.2d at 647.

17 Ibid.

18 Ibid. 
The supreme court affirmed a judgment for plaintiff, thus sustaining the propriety of giving the Last Clear Chance instruction. The court found first that plaintiff was in a position of danger ${ }^{19}$

When Peterson was first seen by Burkhalter, the vehicles were 75 to 50 feet respectively from the intersection, and traveling at speeds which. would place them in the intersection at the same time. To argue that Peterson was not then in a "position of danger' is to disregard reality.

The court went on to find that plaintiff was not guilty of "continuing negligence," saying: ${ }^{20}$

As to the contention that Peterson may not have the benefit of the doctrime of Last Clear Chance because he was physically able to prevent the accident by stopping or turning, Burkhalter ignores the fact that the inattentive plaintiff, as well as the physically helpless one, comes within the scope of the rule. It applies " ... not only where it is physically impossible for him to escape, but also in cases where he is totally unaware of his danger and for that reason unable to escape ...."

The court also found that defendant had actual knowledge of plaintiff's perilous situation and knew or should have known that plaintiff was unaware thereof: ${ }^{21}$

There is ample evidence from which the jury could determine that a reasonably prudent man, knowing the facts of which Burkhalter was aware, should have foreseen that Peterson might not stop or turn his motor scooter. Under such circumstances, it was negligent for Burkhalter to proceed toward the intersection acting upon a contrary assunption.

The court further found that defendant had the last and a clear chance to avoid the accident. It declared that in a proper case an appellate court might say as a matter of law that the defendant did not have a chance which amounted to a "clear one," but that should not be done where the only evidence is to the effect that the defendant could have avoided the accident within the existing time and distance limitations.

\section{What is the Law Today?}

The Selinsky and Peterson cases have cleared the path of the plaintiff's attorney to the jury where the facts entitle him to an instruction on Last Clear Chance. Where the jury is given an instruction on that doctrime and finds from the evidence that it applies, appellate courts will tend strongly to uphold the finding.

The principal question, then, concerns the propriety of giving the Last Clear Chance instruction. The present tendency towards liberality is acknowledged by the Galbraith case, in which it was declared: ${ }^{22}$

\footnotetext{
10 Peterson v. Burkhalter, supre note 9 at 111, 237 P.2d at 979.

20 Ibid.

21 Ibid.

22 Galbraith v. Thompson, 108 A.C.A. 725, 729, 239 P.2d 468, 471 (1952).
} 
Nevertheless it would seem that if there is any evidence which might support a verdict on that theory [Last Clear Chance] there is less danger in giving the instruction than im omitting it. If it is omitted the contributory neghigence doctrime absolutely prevents an award if any contributory negligence is proved, if it is given it only opens the possibility that notwithstanding contributory negligence an award could be granted if a last clear chance for defendant to avoid the accident is found but it does not necessitate it.

Thus it appears that in far more cases than previously, the instruction is available, and where given, a verdict and judgment for the plaintiff is not likely to be reversed if any evidence supports a finding of last clear chance. ${ }^{23}$

\section{What about Comparative Negligence?}

Last Clear Chance was developed and is used by the courts to avoid the rule of contributory negligence, the "harshest" doctrine known to the common law of the 19 th century. ${ }^{24}$ Under the contributory negligence rule $100 \%$ of the loss in an accident may be suffiered by the plaintiff who may only have proximately contributed $1 \%$ to causing the accident, while defendant, whose negligence may have contributed $99 \%$ thereto, escapes without paying any portion of the damages.

Both the Last Clear Chance doctrine and the Comparative Negligence

23 During the last ten years, the following cases have approved the use of Last Clear Chance: Peterson v. Burkhalter, supra note 9 ; Selinsky v. Olsen, supra note 8; Bonebrake v. McCormick, 35 Cal. 2d 16, 215 P.2d 728 (1950); Sills v. Los Angeles Transit Lines, 112 A.C.A. 211, ....... P.2d ....... 1952) ; Brooks v. Willig Trans. Co., 110 A.C.A. 594, 243 P.2d 84 (1952); Galbraith v. Thompson, supra note 22 ; Rodabough v. Tekus, 108 A.C.A. 56, 238 P.2d 25 (1951) (hearing granted in 1952) ; Overacker v. Key System, 99 Cal. App. 2d 281, 221 P.2d 754 (1950) ; Cole v. Ridings, 95 Cal. App.2d 136, 212 P.2d 597 (1949) ; Huggans v. Southern Pacific Co., 92 Cal. App. 2d 599, 207 P.2d 864 (1949); Bragg v. Smith, 87 Cal. App. 2d 11, 195 P.2d 546 (1948); Root v. Pacific Greyhound Limes, Inc., 84 Cal. App. 2d 135, 190 P.2d 48 (1948); Powers v. Shelton, 74 Cal. App. 2d 757, 169 P.2d 482 (1946) ; Paolini v. City of San Francisco, 72 Cal. App. 2d 579, 164 P.2d 916 (1946); Gillette v. City of San Francisco, 58 Cal. App. 2d 434, 136 P.2d 611 (1943) ; Pire v. Gladding McBean \& Co., 55 Cal. App. 2d 108, 130 P.2d 143 (1942) ; Jones v. Yuma Motor Co., 45 Cal. App. 2d 497, 114 P.2d 438 (1941); Ladas v. Johnson's B. \& W. Taxi Co., 43 Cal. App. 2d 223, 110 P.2d 449 (1941).

The following cases in effect rejected the application of the Last Clear Chance doctrine to the facts involved: Luna v. Ames, 108 A.C.A. 640, 239 P.2d 18 (1952); Hosi v. LaVey, 102 Cal. App. 2d 597, 228 P.2d 35 (1951); Allin v. Snavely, 100 Cal. App. 2d 411, 224 P.2d 113 (1950); Haerdter v. Johnson, 92 Cal. App. 2d 547, 207 P.2d 855 (1949); DeVore v. Faris, 88 Cal. App. 2d 576, 199 P.2d 391 (1948); Dickey v. Thornburgh, 82 Cal. App. 2d 723, 187 P.2d 132 (1947) ; Ralston v. Hewitson, 82 Cal. App. 2d 143, 185 P.2d 644 (1947) ; Berton v. Cochran, 81 Cal. App. 2d 776, 185 P.2d 349 (1947); Rather v. City of San Francisco, 81 Cal. App. 2d 625, 184 P.2d 727 (1947); Folger v. Richfield Oil Corp., 80 Cal. App. 2d 655, 182 P.2d 337 (1947) ; Dalley v. Williams, 73 Cal. App. 2d 427, 166 P.2d 595 (1946) ; Mangler v. Pacific Electric Ry.,71 Cal. App. 2d 815, 163 P.2d 774 (1945); Ravettino v. City of San Diego, 70 Cal. App. 2d 37, 160 P.2d 52 (1945); Uribe v. McCorkle, 63 Cal. App. 2d 61, 146 P.2d 22 (1944); Keller v. Arden Farms, 59 Cal. App. 2d 506, 139 P.2d 47 (1943); Brown v. McCuan, 56 Cal. App. 2d 35, 132 P.2d 838 (1942); Johnson v. Sacramento Northern Ry., 54 Cal. App. 2d 528, 129 P.2d 503 (1942) ; Jones v. Heinrich, 49 Cal. App. 2d 702, 122 P.2d 304 (1942); Lasch v. Edgar, 46 Cal. App. 2d 726, 116 P.2d 949 (1941). Query, would any of these cases have been decided differently had it come up after the Selinsky and Peterson cases?

24 Green, Illinois Negligence Law, 39 IIL. L. REv. 36 (1944). 
theory are attempts to mitigate the harshness of the contributory negligence rule. The increasing liberality of the courts towards Last Clear Chance indicates a parallel increasing distaste for the contributory negligence rule. But Last Clear Chance is inadequate to cope with the contributory negligence nemesis in two respects:

1. The doctrine is inapplicable to the many cases of contemporaneous negligence, for the defendant's negligence must be subsequent to the plaintiff's in order that defendant may have the "last" chance to avoid harnn. ${ }^{20}$

2. It is unfair to put $100 \%$ of the loss on the defendant where the plaintiff's antecedent negligence prepared the very situation producing the application of the doctrine.

Under inodern comparative negligence statutes, a claimant's negligence does not bar his recovering of damages but simply operates to dimimsh the amount in proportion to his contribution to the causing of the injury. ${ }^{26}$

Problems of multiple plaintiffs or defendants, solvency of parties, and computation of the relative degree of fault in terms of percentages raise difficulties in the practical application of the comparative negligence theory. These problems are not insurmountable. In several states and in Canada, comparative negligence has been applied and has produced a much more equitable solution to the problem of adjusting loss between parties than any other method known, for it prevents the burden from falling entirely on one party or the other. ${ }^{27}$

25 Prosser, TORTS 415 (1941).

26 Federal Earployers' Liability Act, 35 Stat. 65 (1908), as amended, 36 Stat. 291 (1910), 45 U.S.C. 51 et seq. (1946); 41 STAT. 988, 1007 (1920), 46 U.S.C. 688 (1946) (Jones Act); ARR. Stat, tit. 73, §73.1004 (1947); FLA. Stat. c. $768 \S 768.06$ (1949); GA. Code, tit. 105, c. 105.603; Iowa CoDE, c. 619, §619.11 (1946); MacH. CoMP. LAws, c. 419, \$419.52; MIss. Code ANN. § 1454 (1942); NEb. Rev. Stat. c. 25, § 25.1151; S. D. Laws, c. 160 (1941); WIs. STat., c. 331, § 331.045 (1949) ; AIberta Rev. Stat., c. 116 (1942); Brit. Col. Stats., c. 8 (1925) ; New BR. Rev. Stats. 1927, c. 143, p. 1758 (1927); Nov. Sc. Stat., c. 3 (1926); ONT. Stat., 20 GEo. V, c.27 (1930), revised, 21 GEo. V, c. 26 (1931).

27 Turk, Comparative Negligence on the March, 28 CEI-KENT REv. 189, 207 (1950). 